\title{
Whey powder in the preparation of pastry creams
}

${ }^{1}$ Delmi Bouras Amina, ${ }^{1}$ Megatli Ismail and ${ }^{2}$ Dilmi Bouras Abdelkader

\author{
${ }^{1}$ Saad Dahleb, Blida University \\ ${ }^{2}$ Natural Bioresource Laboratory, H.B. Chlef University
}

\begin{abstract}
Algeria imports more than half of her milk requirements. The annual bill exceeds 1 billion dollars. Faced with this situation, she must now think about finding a way to reduce this dependence by replacing cow's milk, in part, with another commodity abundant in the world and cheaper. In this work we used whey powder in the preparation of pastry creams. The results showed that $80 \%$ of tasters find the CA cream (100\% whey) is extremely pleasant and gave it a 9/9 rating. The comparison between different pastry creams revealed that the cream prepared with 100\% whey $\left(\mathrm{CA}_{\mathrm{A}}\right)$ presents the best appreciations. Similarly, it presents texture improvements, smooth and homogeneous with a clear appearance and a very pleasant smell. Among the positive points we noted that the addition of whey improves water retention and reduces syneresis. Whey creams have kept a good quality after 7 days of storage at $6^{\circ} \mathrm{C}$.
\end{abstract}

Key words : whey, pastry cream s.

\section{Introduction}

Algeria is considered a major consumer of milk and by-products, and this is due to food traditions, the nutritional value of milk, its substitution for relatively expensive meats and the support of the state, all of which are parameters which boosted the demand. The price of this strategic food is increasing, given the large and growing global demand [1].

Whey, a by-product of cheese making or casein production, can be defined as decaseinated milk. It has become essential to treat it to avoid environmental pollution [2]. The interest in whey powder depends essentially on the protein fraction it contains [3]. This powder is less expensive than milk powder $[4,5]$. The nutritional and functional characteristics of whey proteins are related to their structure and biological functions. Native whey proteins (globulins and lactalbumin), which make up 11 percent of the powders, present useful functional properties. Food Fortification is cost effective and is done for foods which are consumed by mass, without disturbing color, taste and odor of the food [6]. Therefore, we were interested in the substitution of milk with whey, a more available, protein-quality and low-cost product in the manufacture of highly consumed foods in Algeria and around the world.

In this work, we used whey powder in the preparation of pastry creams for various reasons: 
- Get rid of the environment of this very polluting and bulky waste;

- Valorization of a rich and low-cost by-product. It is possible to produce whey-based foods at affordable prices and rich in protein, lactose, and water-soluble vitamins without relying on eggs, meat and dairy products that weigh heavily on the economy and the environment;

- Allow certain casein intolerants to safely consume whey creams, ice creams, etc.

\section{Material and methods}

This work was carried out at the PPCA Laboratory of the Hassiba Ben-Bouali Chlef University, as part of an agreement between the LBRN Laboratory and the Lactamel group of Sidi-Belabès.

\subsection{Material}

\subsubsection{Raw material}

The whey powder used comes from the European Union, imported by the Lactamel group of SidiBelabès. Bacteriological and chemical specifications are known. It is a stabilized powder between demineralized whey and vegetable fat, It is a dairy preparation that can be used for many applications (pastry cream, ice cream, baked goods...).

\subsubsection{Other ingredients}

We used other ingredients from the trade: milk, water, flour.

\subsection{Methods}

The food preparation that we have chosen is whey custard. Different dairy liquids have been prepared using whey powder :

$\neg 100 \%$ milk : $10 \mathrm{~g}$ of milk powder in $90 \mathrm{ml}$ of water : control sample $=\mathrm{L} 0$,

$\neg 50 \%$ of milk powder $(5 \mathrm{~g})+50 \%$ of whey powder $(5 \mathrm{~g})$ in $90 \mathrm{ml}$ of water $=\mathrm{L} 50$.

$\neg 100 \%$ whey : $10 \mathrm{~g}$ of whey powder in $90 \mathrm{ml}$ of water $=\mathrm{L} 100$.

To elucidate the effect of the concentration of whey powder on the quality of our products; we prepared three pastry cream samples :

- Cream A $=\mathrm{CA}=\mathrm{L} 100+$ other ingredients,

- Cream $\mathrm{B}=\mathrm{CB}=\mathrm{L} 0+$ other ingredients,

- Cream $\mathrm{C}=\mathrm{CC}=\mathrm{L} 50+$ other ingredients. 


\subsubsection{Preparation of the pastry cream}

For $100 \mathrm{ml}$ of dairy liquid (L0 or L50 or L100) we add : 60g of starch, 24g of egg, 20g of juice and $20 \mathrm{~g}$ of margarine. The whole is put in a saucepan and heated to $70-80^{\circ} \mathrm{C}$.

The method used for the preparation of the pastry cream is to mix energetically continuously the other ingredients of the recipe : egg yolks, sugar and starch. Gradually add the milk liquid preparation (L0 or L50 or L100) and mix vigorously. Add lemon juice while stirring the cream with a whisk.

Pour the pastry cream ( $\mathrm{CA}$ or $\mathrm{CB}$ or $\mathrm{CC}$ ), obtained in a bowl, then add butter. Keep the cream in the refrigerator before using.

\subsubsection{Evaluation of the organoleptic quality of breads}

The hedonic notation test is chosen for this sensory evaluation for the following reasons. It is not expensive, does not require specialized tasters and allows to compare the consumer's appreciation of different samples [7].

For the tasting (70 volunteers) we chose the three types of cream: $\mathrm{CA}, \mathrm{CB}_{\mathrm{B}}, \mathrm{CC}$. Volunteers are chosen at random, of different sexes and ages (20 to 60 years). Everyone is invited to taste a piece of each bread; then evaluate them by giving a score of 1 to 9 on the scoring sheet that was developed according to the 9-point hedonic scale.

\subsubsection{Evaluation of the physicochemical quality}

The physicochemical characterization of the different samples was made by the determination of their dry matter, the humidity and the monitoring of their $\mathrm{pH}$ during 7 days of storage at $6{ }^{\circ} \mathrm{C}$.

\subsubsection{Determination of $p H$}

Performed using $\mathrm{pH}$ meter. The $\mathrm{pH}$ reading is done on the screen after stabilization.

\subsubsection{Determination of the total dry extract}

Also according to ISO [8] which consists of : Weigh $5 \mathrm{~g}$ of the pastry cream, put in a kneaded glass box; dry and tare, then introduce the sample into the oven at $103{ }^{\circ} \mathrm{C}$ for 3 hours, 1 hour and $1 / 2$ hour. The dry extract of the pastry cream is expressed as a percentage by weight by the following formula : $\quad(M 1-M 0) /(M 2-M 0) \times 100$

M0: Mass in grams of the empty cup, M1: Mass in grams of the cup and the residue after desiccation, M2: Mass in grams of the cup and the test sample. 


\subsubsection{Determination of the moisture content}

Moisture is calculated by the following formula :

$\boldsymbol{H} \%=\mathbf{1 0 0}-\boldsymbol{T D E} \%$ TDE: Total Dry Extract \%

\subsubsection{Bacteriological analyzes}

The pastry cream samples were subjected to a bacteriological analysis, or we carried out the research and, in case of presence, the enumeration of the germs prescribed in table 1 . These seeds are obligatorily sought in these products according to the Algerian norm.

\begin{tabular}{|c|c|}
\hline Germ sought & $\begin{array}{l}\text { Growth condition } \\
\text { (aerobically) }\end{array}$ \\
\hline Mesophilic anaerobic total flora & $37^{\circ} \mathrm{C} / 24 \mathrm{~h}$ \\
\hline Total coliforms & $37^{\circ} \mathrm{C} / 24 \mathrm{~h}$ \\
\hline Fecal coliforms & $44^{\circ} \mathrm{C} / 24 \mathrm{~h}$ \\
\hline Salmonella & $37^{\circ} \mathrm{C} / 24 \mathrm{~h}$ \\
\hline Staphylococcus aureus & $37^{\circ} \mathrm{C} / 24 \mathrm{~h}$ \\
\hline Yeasts and molds & $25^{\circ} \mathrm{C} / 5 \mathrm{j}$ \\
\hline
\end{tabular}

The search and enumeration of these germs is carried out according to the ISO [8] standard which consists in : prepare decimal dilutions. Aseptically carry from the chosen dilution $1 \mathrm{ml}$ and pour it on the surface of the box in case of research and in depth in case of enumeration.

- Incubate the dishes according to the growth conditions indicated in Table 1.

\section{Results}

\subsection{Organoleptic characteristics of pastry creams}

\subsubsection{General appearance of the cream}

Our five senses play important and distinct roles in sensory analysis during organoleptic testing. Personal appreciation therefore results from the combination of a very subtle set of all these mechanisms, culture, and information memorized differently by each of us. The general appearance of the cream is shown in Figure 1. 

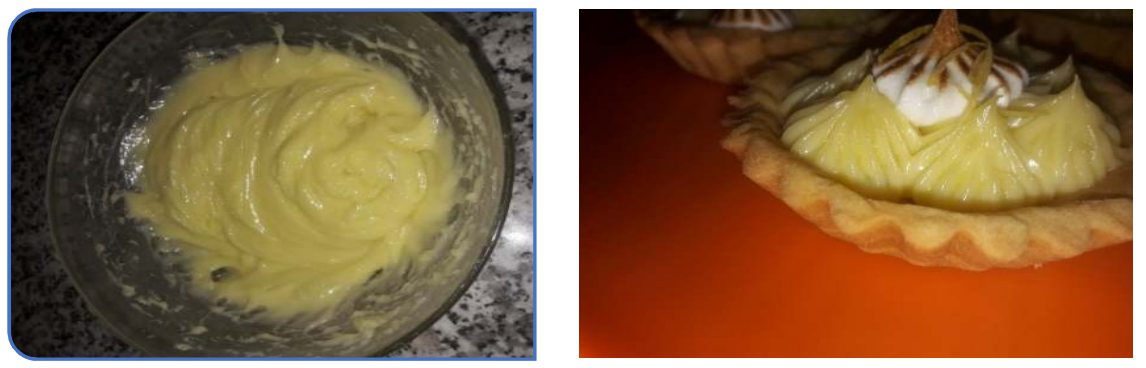

Figure 1: Appearance of the cream: the example of $100 \%$ whey (CA)

\subsubsection{Tasting test results}

The organoleptic quality of the three samples of the cream $(\mathrm{CA}, \mathrm{CB}$ and $\mathrm{CC})$ was evaluated by 70 volunteer tasters and the results found are shown in Figure 2.

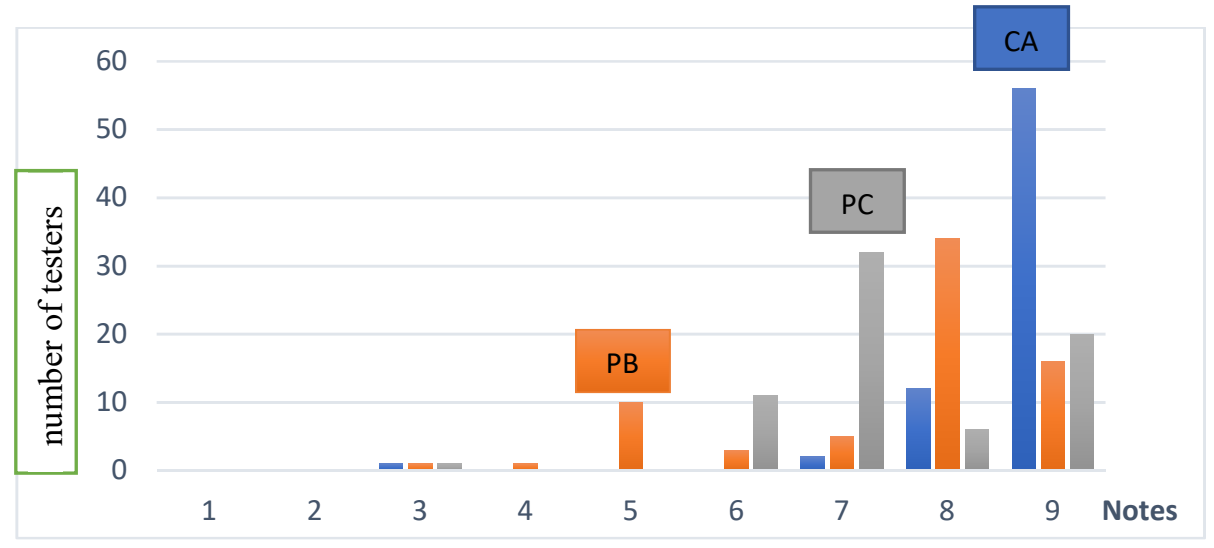

Figure 2 : Graphical representation of the pastry cream grading test results
1. extremely unpleasant
2. very unpleasant
3. unpleasant
4. quite unpleasant
5. neither pleasant nor unpleasant
6. quite pleasant
7. Pleasant
8. Very nice
9. Extremely pleasant

The overall assessment of the results shows that :

- $80 \%$ of tasters find that CA cream is extremely pleasant and give it a $9 / 9$ rating.

$-48.5 \%$ of tasters find that the cream $\mathrm{CB}$ is very pleasant and affect him a score of $8 / 9$.

$-45.7 \%$ of tasters find that the cream CC (50\% whey) is pleasant and affect him a score of 7/9.

\subsubsection{Organoleptic characteristics of the different creams}

The different organoleptic characteristics according to the composition of the cream and the results of the tests of appreciation of this quality are given in Table 2. 
The tasters found that the pastry cream $\mathrm{CB}$ has a creamy texture and a limpid appearance and a matte color. In general, the comparison between different pastry creams revealed that the cream prepared with $100 \%$ whey (CA) has the best appreciations.

Table 2: Organoleptic characteristics of different breads : Consumer reviews

\begin{tabular}{lccc}
\hline $\begin{array}{c}\text { Bread } \\
\text { Character }\end{array}$ & CA & CB & CC \\
\hline Aspect & Brillon & Dull & Clear \\
Texture & Creamy and homogeneous & Creamy and homogeneous & Creamy and homogeneous \\
Odour & Very nice and pronounced & Pleasant & Pleasant \\
Taste & Very good & Good & Very good \\
Aroma & Acid-sweet & Acid-sweet & Acid-sweet \\
\hline
\end{tabular}

During the preparation of pastry creams we noticed that the addition of whey leads to several positive points :

- brings back a more stable emulsion,

- improves water retention and reduces syneresis during thawing,

- improves the sensory properties,

- allows a good combination of stabilizers and ensures a strong gel and a stable heat,

- reduces the costs of the recipe.

\subsection{Preserving custard creams}

To follow the evolution of the organoleptic quality we kept the creams $(\mathrm{CA}, \mathrm{CB}$ and $\mathrm{CC})$ at $6{ }^{\circ} \mathrm{C}$ for a precise duration. The evolution of quality corresponds to a modification of texture and aromatic properties over time [9].

The results show that creams containing high whey percentages maintain a smooth and shiny outer texture and do not produce exudate. This textural quality persists until the 7 th day and deteriorates gradually to be destructured around the 12 th day (Figure 3). So, for the $100 \%$ milk $(\mathrm{CB})$ cream, the loss of the smooth and shiny texture begins to be perceived from the 5th day with exudation starting from the 6th day. 

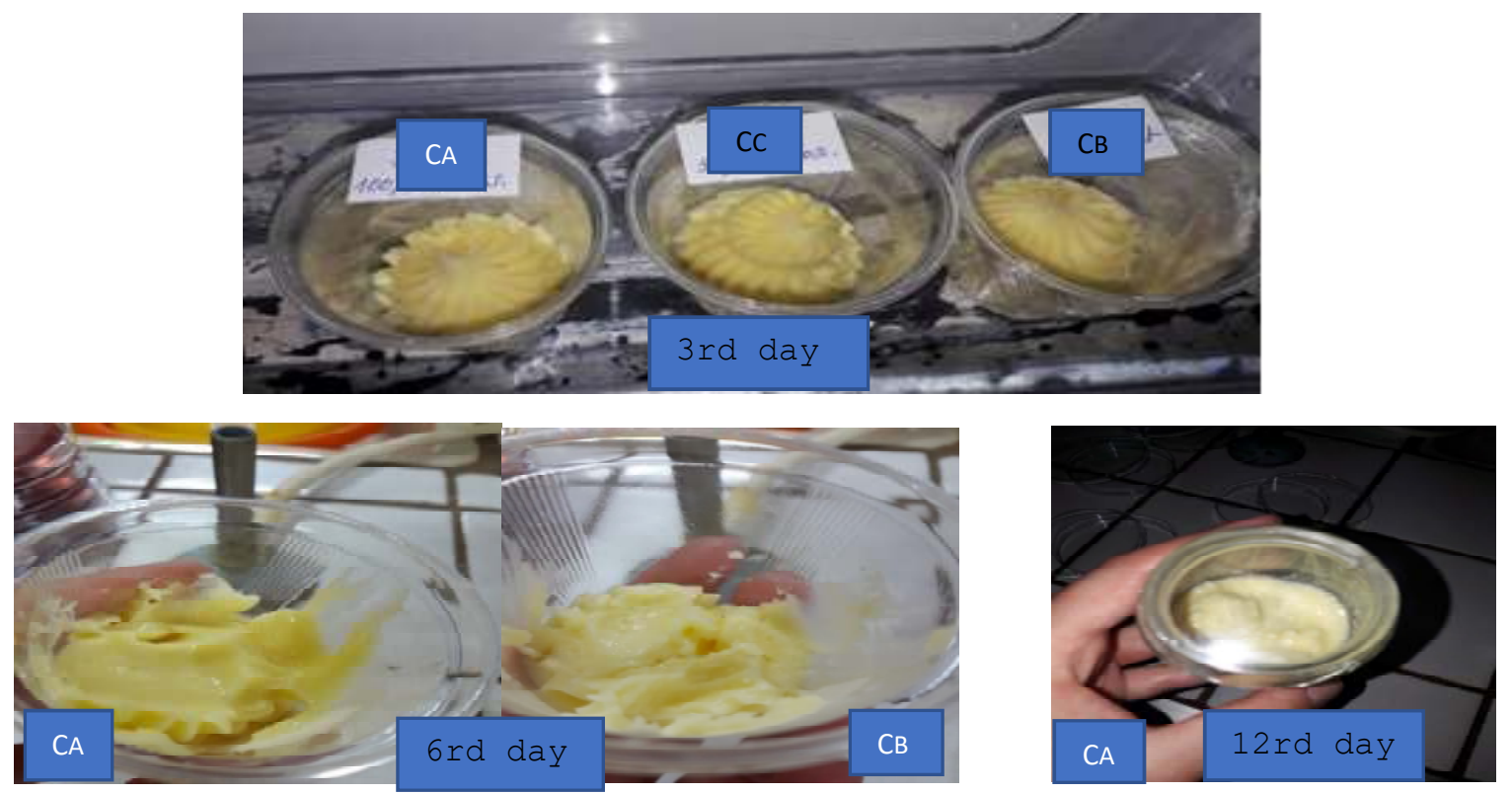

Figure 3: Evolution of the organoleptic quality of creams at $6^{\circ} \mathrm{C}$

\subsection{Evaluation of the physicochemical quality of pastry creams}

\section{1. $p H$}

Variations in $\mathrm{pH}$ values during the preservation of custard creams evolved differently depending on whether whey was added or not. The results found are shown in Figure 4.

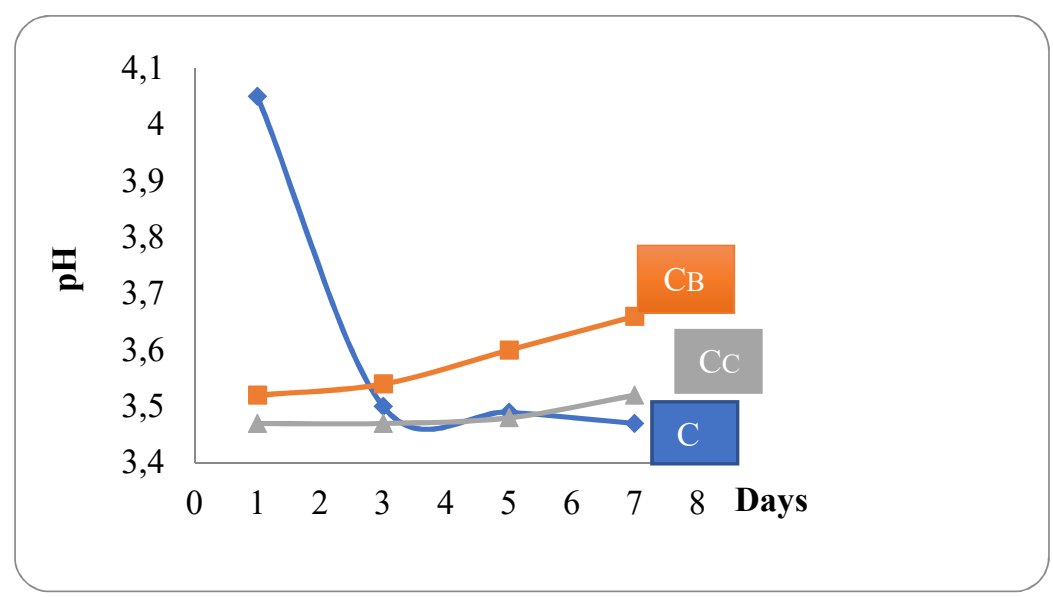

Figure 4: Evolution of the $\mathrm{pH}$ of pastry cream during storage.

Variations in $\mathrm{pH}$ values during cream preservation depend on the time of fermentation and their initial $\mathrm{pH}$. For the 02 pastry creams $\mathrm{CB}$ and $\mathrm{CC}$, the evolution of the $\mathrm{pH}$ is regular and increases appreciably with time but remains very low (2 to $4 \%$ ). 


\subsubsection{Total dry extract and moisture}

The determination of the water content is important since it determines the accuracy of the analytical results related to the dry matter or moisture content of the product. The results of the three pastry cream samples are as follows : $\mathrm{CA}=50 \%, \mathrm{CB}=48 \%$, and $\mathrm{CC}=52 \%$.

\subsection{Microbiological evolution of pastry creams}

The results of the counts of bacteria (FAMT, total coliforms, fecal coliforms, Salmonellae, Staphylococcus aureus) of the different pastry creams ( $\mathrm{CA}, \mathrm{CB}$ and $\mathrm{CC})$ do not reveal the presence of any colony during the 7 days of storage. The logical result of the fact that pastry creams have been baked at a very high temperature.

\section{Discussion}

For the consumer, the notion of good or bad cream is closely related to these characteristics. From a professional point of view, the precise description, textures and tastes, allows a progress towards a better control of the know-how to answer to the precise expectations of the consumers [9]. The $\mathrm{CA}$ and $\mathrm{CC}$ creams have almost identical but better characteristics than the $\mathrm{CB}$ cream with texture improvements, smooth and homogeneous with a clear appearance and a very pleasant smell (CA) because the whey powder has pushed the expression of the flavors (acid, vanilla, sweet). In general, the comparison between different pastry creams revealed that the cream prepared with $100 \%$ whey (CA) has the best appreciations. The whey powder has an excellent property of solubility and wettability, and is ideal in the use of different types of pastry creams [10]. Among the positive points of whey is the improvement of water retention and the reduction of syneresis.

Whereas for the pastry cream $\mathrm{CA}_{\mathrm{A}}$ the initial $\mathrm{pH}$ was high because the concentration of citric acid (addition) was higher. Then we saw a decrease followed by a stabilization due to a dilution of the acid. The dry materials and the moisture of the different pastry creams are equivalent and the difference is negligible. Dry matter is much larger and moisture is less important when whey content is important. Because the latter is richer in fat that remains in the total dry extract.

The absence of microorganisms is logical results because the different breads were baked at a very high temperature. Similarly, the results of research and enumeration of yeasts and molds were negative for the various pastry creams. In addition, no contamination was recorded despite the absence of synthetic preservatives. 


\section{Conclusion}

The overall appreciation of the volunteer tasters is that the three cream samples have good organoleptic characteristics: appearance, texture, smell, taste and aroma; with a better benefit for 100\% whey cream (CA). The latter has texture improvements, smooth and homogeneous with a clear appearance and a very pleasant smell, because the whey powder has pushed the expression of flavors by improving the sensory properties of the cream. Among the other positive aspects of whey is the improvement of water retention and the reduction of syneresis.

The results revealed no presence of pathogenic bacteria or yeasts or fungi in all the samples that were analyzed, indicating good hygienic preparation conditions.

Through these results, it is necessary to continue this work by the following parties:

- Elaborate foods with added protein content using by-products of the food industry (whey) and thus make available to the Algerian consumer products of nutritional quality, organoleptic and microbiological at reasonable price;

- Research of bioactive molecules (casein intolerance) in whey for their addition in widely consumed food products in Algeria.

\section{Acknowledgements}

My heartfelt thanks go to Dr. Assal N., President of the Lactamel Group, for his help in acquiring whey powder.

\section{References}

[1] Nemar F, Dilmi Bouras A, Koiche M, Assal N-E, Mezaini A and Prodhomme J. Bread quality substituted by Potato starch instead of wheat flour. Ital J Food Sci $2015 ; 27: 345-350$.

[2] Lachebi S. Valorisation des rejets de l'industrie laitière par technique membranaires (ultrafiltration). Mémoire de Magister ; Université M.B. Boumerdes, Algeria ; 2009, 151p.

[3] Ilker E, Mushsin C, Sebnem H. Separation of whey Components by using ceramic composite membranes. desalination $2006 ; 189: 87-91$

[4] Audic JC, Chaufer B, Daufin G. (). Non-food applications of milk components and dairycoproducts : A review. Lait $2003 ; 83$ : 417-438. 
[5] Schuck P, Bouhallab S, Durupt D, Vareille P, Humbert JP and al. Séchage des lactosérums et dérivés: rôle du lactose et de la dynamique de l'eau. Le Lait 2004 ; 84 (3) : 243-268.

[6] Sharma R and Sharma R. Micronutrient Enriched Food Ingredients - An Easy Way to Stay Healthy. EC Nutrition $2018 ; 13.3: 89$.

[7] Boutrolle I. Mesure de l'appréciation des aliments par les consommateurs : état des pratiques et propositions méthodologiques [en ligne]. Thèse de doctorat, AgroParisTech 2007.

[8] ISO 6611. Lait et produits laitiers. Dénombrement des unités formant colonie de levures et/ou moisissures - Comptage des colonies à $25^{\circ} \mathrm{C} ; 2004$.

[9] Roussel P and Chiron H. (2002). Les pains français : évolution, qualité, production 2, France: MAE-ERT I Editeurs. ISBN/2-84601-693-3.

[10] Chantarasiri A, Meevootisom V, Isarangkul D, Wiyakrutta S. Effective Improvement of DPhenylglycine Aminotransferase Solubility by Protein Crystal Contact Engineering. J Mol Microbiol Biotechnol 2012; 22 : 147-155 